\title{
PROXIMATE AND MINERAL COMPOSITION OF TWO SOUPS AS PREPARED IN THE SOUTH-WEST AND SOUTH-SOUTH REGIONS OF NIGERIA
}

\author{
O. O. LAWAL, I. B., UMOH, M. I. AKPANABIATU, I. O. WILLIAMS AND M. A. AGIANG
}

(Received 29, October 2008; Revision Accepted 15, January 2009)

\begin{abstract}
The proximate and mineral composition of okro and ogbono soups prepared with two different Nigeria traditional (South/West, i.e. Yoruba, and South/South, i.e. Efik/lbibio) recipes was assessed in this study. The crude protein, fat, $\mathrm{Ca}$ and Na nutrient composition ( $30.53 \pm 0.15 \%$ dry weight, $32.58 \pm 1.32 \%$ dry weight, $1132.42 \pm 9.26 \mathrm{mg} / 100 \mathrm{DM}$ and $1803.95 \pm 130.47 \mathrm{mg} / 100 \mathrm{DM}$ respectively), of okro soup prepared with South/South (S/S) recipe were significantly higher $(P<0.01)$ when compared to the corresponding composition $(25.39 \pm 0.15 \%$ dry weight, $26.53 \pm 2.29 \%$ dry weight, $1000.00 \pm 33.95 \mathrm{mg} / 100 \mathrm{DM}$ and $1329.28 \pm 120.44 \mathrm{mg} / 100 \mathrm{DM}$ respectively) prepared with South/West (S/W) recipe. However, carbohydrate, moisture, and $\mathrm{K}$ composition $(25.26 \pm 1.04 \%$ dry weight, $74.99 \pm 4.43 \%$ wet weight, and $673.34 \pm 8.61 \mathrm{mg} / 100 \mathrm{DM}$ respectively) of okro soup prepared with South/South (S/S) recipe were significantly lower $(P<0.05)$ compared to the corresponding composition $(34.55 \pm 0.06 \%$ dry weight, $92.99 \pm 6.53 \%$ wet weight, and $797.81 \pm 5.63 \mathrm{mg} / 100 \mathrm{DM}$, respectively), prepared with South/West $(\mathrm{S} / \mathrm{W})$ recipe . Also, the crude protein, fibre, caloric value and Na composition $(21.76 \pm 1.29 \%$ dry weight, $3.96 \pm 0.26 \%$ dry weight, $548.37 \pm 8.96 \%$ dry weight and $3147.05 \pm 298.81 \mathrm{mg} / 100 \mathrm{DM}$ respectively) of ogbono soup prepared with South/South (S/S) recipe were significantly higher $(P<0.01)$ when compared to the compositions $(19.89 \pm 0.13 \%$ dry weight, $3.15 \pm 0.12 \%$ dry weight, $540.82 \pm$ $4.81 \%$ dry weight and $1411.33 \pm 34.22 \mathrm{mg} / 100 \mathrm{DM}$ respectively) prepared with South/West (S/W) recipe. The carbohydrate, $\mathrm{Mg}, \mathrm{P}$, and Ca compositions $(24.95 \pm 0.08 \%$ dry weight, $192.55 \pm 17.94,448.92 \pm 16.41$, and $1109.59 \pm$ $10.80 \mathrm{mg} / 100 \mathrm{DM}$, respectively) of ogbono soup prepared with South/South (S/S) recipe were significantly lower $(\mathrm{P}<0.01)$ when compared to the corresponding composition $(32.38 \pm 1.62 \%$ dry weight, $311.47 \pm 12.25,470.69 \pm$ 11.23 , and $1956.70 \pm 10.80 \mathrm{mg} / 100 \mathrm{DM})$ prepared with South/West $(\mathrm{S} / \mathrm{W})$ recipe. From the result of this study, it is observed that $S / S$ traditional recipe for the cooking of okro and ogbono soups yielded a more nutritious preparations than the S/W traditional recipe. On the basis of this, S/S traditional recipe may be highly recommended for the cooking of the two soups.
\end{abstract}

KEYWORDS: South-West (S/W): Yoruba, South-South (S/S): Efik \& Ibibio.

\section{INTRODUCTION}

Some Nigerian soups have been analysed and the proximate and elemental composition results have been published (Umoh 1972, Udosen 1995, Akpanabiatu et al 1998). Most Nigerian soups contain meat, fish, oil, vegetables and water. Irvingia gabonensis has been reported to contain low protein and high fat values (Aladesey et al, 1983; Ekpe 1997). Spindler and Akasionu (1985) reported the seed of Irvingia gabonensis to contain $38.9 \%$ dietary fibre and $2.2 \%$ crude fibre while the fatty acid composition showed it to be highest in lauric and myristic acids. In a study on the efficacy of Irvingia gabonensis seeds on the management of obesity, Ngoddi et al (2005) observed a decrease in the mean body weight of a group of obese participants. The seed was reported to have induced a decrease in weight of $2.91 \%$ after two weeks of use with significant decrease in the total cholesterol, LDL-cholesterol and triglyceride with increase in the HDL-cholesterol. However, there is a dearth of information on Irvingia gabonensis in its soup form despite its popularity in the two regions being considered.

Previous studies have shown Hibiscus esculentus to contains adequate mineral and a good proximate composition in the raw, dried and cooked forms (Platt 1965, Oyenuga 1968; Eyo et al 1981; Akpanabiatu et al 1998). Ekaidem (1995) reported the proximate composition of okro soup (South-South) to range from $5.50 \pm 0.5$ for total ash to $38.81 \pm 0.15$ for crude protein $\%$ dry matter. The methods of processing and preparation of foods have been shown to have effects on the bioavailability of the nutrients in the foods (Bender, 1966; Eka, 1984; Latunde-Dada, 1990). The methods of cooking the soups in the two regions differ considerably and their proximate and elemental composition have not been previously compared.

O. O. Lawal, Biochemistry Department, College of Medical Sciences, University of Calabar, P. M. B. 1115, Calabar - Nigeria.

I. B., Umoh, Biochemistry Department, College of Medical Sciences, University of Calabar, P. M. B. 1115, Calabar - Nigeria.

M. I. Akpanabiatu, Biochemistry Dept. College of Medical Sciences, University of Calabar, P. M. B. 1115, Calabar -

I. O. Williams, Biochemistry Department, College of Medical Sciences, University of Calabar, P. M. B. 1115, Calabar - Nigeria

M. A.. Agiang, Biochemistry Department, College of Medical Sciences, University of Calabar, P. M. B. 1115, Calabar - Nigeria. 
This study was on processed and prepared ogbono (Irvingia gabonensis) and okro (Hibiscus esculentus) soups by the methods used in the SouthWest (S/W) and South-South (S/S) regions of Nigeria and the soups were analysed for crude protein, crude fat, crude fibre, carbohydrate, ash, moisture, caloric value and mineral elements $\mathrm{Mg}, \mathrm{P}, \mathrm{K}, \mathrm{Ca}$ and $\mathrm{Na}$.

The study was aimed at determining which of the $S / S$ and S/W traditional recipe for the cooking of okro and ogbono soup is more nutritious based on the nutrient content or composition of the soups.

\section{MATERIALS AND METHODS}

All the materials are shown in table 1. Materials for the okro soup (South-West) were okro, locust bean (Parkia biglobosa), blended melon seed (citrullus villgaris), crayfish and knorr cubes while the complimentary stew contained meat, tripe, cowleg, liver, spleen, intestine, tomatoes, pepper, onions, palm oil and knorr cube. The ogbono soup (S/W) contained blended ogbobo seed, meat, cowleg, liver, spleen, tripe, intestine, pepper and knorr cube.

Materials for okro soup (S/S) were okro, pumpkin leaves (Telfaira occidentalis), a little quantity of ogbono seed (for the drawing effect) meat, dried fish, stock fish, crayfish, periwinkle, clam, cowskin, pepper, onions, palm oil and knorr cubes while ogbono soup $(S / S)$ contained the same ingredients except that the quantity of okro and ogbono varied. All the materials for the soups were purchased from Ika-lka Oqua market in Calabar Municipality, Cross River State, Nigeria in March 2006 and were used to prepared the soups which were analysed in the same month. The ingredients were processed and the soups were prepared using the known conventional culinary methods of these regions. Three samples of each soup were homogenized in a Kenwood blender and dried at $55^{\circ} \mathrm{C}$ for $36 \mathrm{hrs}$ in an oven (Astell-Hearson, London, UK). The dried samples were stored individually in glass containers with plastic screw caps and kept in the freezer $\left(-4^{\circ} \mathrm{C}\right)$ until required for analysis.

All the analyses were carried out in triplicate within 2 weeks of their preparation. Proximate determination was by A.O.A.C (1993) while the mineral element composition was determined using kit methods after acid digestion. Caloric values were obtained by calculation.

The standard student ' $\mathrm{t}$ ' test was used for statistical analysis.

Table I: Recipes (content in grams) of the soups

\begin{tabular}{l|c|c|c|c|c} 
Condiments & $\begin{array}{c}\text { Table I: Recipes (content in grams) of the soups } \\
\text { Okro soup } \\
\text { (S/W) }\end{array}$ & $\begin{array}{c}\text { *Stew (S/W) } \\
\text { used for } \\
\text { okro }\end{array}$ & $\begin{array}{c}\text { Ogbono } \\
\text { soup (S/W) }\end{array}$ & $\begin{array}{c}\text { Okro soup } \\
\text { (S/S) }\end{array}$ & Ogbono soup (S/S) \\
\hline Okro & 265 & - & - & 237 & 40 \\
Ogbono & - & - & 347 & 40 & 186 \\
Meat & - & 294 & 425 & 281 & 226 \\
Cowskin & - & - & - & 172 & 154 \\
Cowleg & - & 79 & 132 & - & 47 \\
Intestine & - & - & 212 & - & - \\
Liver & - & 64 & 176 & - & - \\
Spleen & - & 62 & -1 & - & - \\
Tripe & - & 126 & 173 & - & - \\
Crayfish & - & - & 10 & 93 & 64 \\
Dried fish & - & - & - & 186 & 154 \\
Stock fish & - & - & - & 76 & 20 \\
Periwinkle & - & - & - & 84 & 33 \\
Pumpkin leaves & - & - & - & 79 & 25 \\
Pepper & - & 30 & 30 & 23 & 78 \\
Palm oil & - & 107 & 100 & 56 & - \\
Tomatoes & - & 337 & - & - &
\end{tabular}

Note: $\quad$ *Yoruba people of S/W use stew with okro hence the recipe for stew. The little quantity of ogbono in the okro soup (S/S) was to enhance the drawing effect.

Source: $\quad$ Lawal, O. O. (2007) Nutritional evaluation of Irvingia gabonensis and Hibiscus esculentus as prepared in the South-West and South-South regions of Nigeria.

\section{RESULTS}

The proximate compositions are shown in table II. Okro (S/S) had the highest crude protein content $30.53 \pm 0.15 \%$ dry weight while ogbono soup $(S / W)$ had the lowest value at $19.89 \pm 0.13$. The crude fat content was higher in ogbono soup (S/S) $40.17 \pm 0.97$ than in all the other soups. The carbohydrate content is lower in the two South-South soups at $25.26 \pm 1.04$ and $24.95 \pm$ 0.08 for okro soup and ogbono soup respectively. Crude fibre content is lower in ogbono soup (S/W) at
$3.15 \pm 0.12$. The caloric value in $\mathrm{Kcal} / 100 \mathrm{~g}$ in ogbono soup $(\mathrm{S} / \mathrm{S})$ was the highest being $548.37 \pm 8.96$.

The mineral element composition are as shown in table II. Ogbono soup (S/W) had the highest magnesium content $311.47 \pm 12.25 \mathrm{mg} / 100 \mathrm{~g}$ dry weight while ogbono soup (S/S) had the lowest value at 192.55 + 17.94. Ogbono soup (S/W) also had the highest calcium content $1956.70 \pm 10.80$. The highest sodium content was in ogbono soup (S/S) $3147.05 \pm 298.81$ and okro soup $(\mathrm{S} / \mathrm{W})$ had the lowest $1329.28+120.44$. 
Phosphorus value was $556.81+10.94 \mathrm{mg} / 100$ dry weight for okro soup (S/S), potassium contents was highest in okro soup $(S / W) 797.81 \pm 5.63 \mathrm{mg} / 100 \mathrm{~g}$ dry weight.

Table II: Proximate nutrient composition of Hibiscus esculentus (Okro) and Irvingia gabonensis (Ogbono) soups as prepared in the South-West and South-South regions of Nigeria (\% dry weight).

\begin{tabular}{l|ll|l|l|l|l|c|c}
\multicolumn{1}{c|}{ Soup } & \multicolumn{2}{|c|}{$\begin{array}{c}\text { Crude } \\
\text { protein }\end{array}$} & Crude fat & $\begin{array}{c}\text { Crude } \\
\text { fibre }\end{array}$ & $\begin{array}{c}\text { Carbohydr } \\
\text { ate }\end{array}$ & Ash & *Moisture & $\begin{array}{c}\text { Caloric } \\
\text { value }\end{array}$ \\
\hline Okro (S/W) & 25.39 & \pm & $26.53 \pm$ & $3.57 \pm$ & $34.55 \pm$ & 9.96 & 92.99 & 478.5 \\
& 0.15 & & 2.29 & 0.13 & 0.06 & \pm 0.72 & \pm 6.53 & \pm 3.02 \\
\hline Okro (S/S) & 30.53 & \pm & $32.58 \pm$ & 3.16 & $25.26 \pm$ & 8.47 & 74.99 & $516.38 \pm$ \\
& 0.15 & & 1.32 & \pm 0.26 & 1.04 & \pm 0.22 & \pm 4.43 & 3.81 \\
\hline Ogbono & 19.89 & \pm & $36.86 \pm$ & $3.15 \pm$ & $32.38 \pm$ & 7.12 & 69.99 & $540.82 \pm$ \\
$(\mathrm{S} / \mathrm{W})$ & 0.13 & & 0.04 & 0.12 & 1.62 & \pm 0.57 & \pm 2.19 & 4.81 \\
\hline Ogbono & 21.76 & \pm & $40.17 \pm$ & $3.96 \pm$ & $24.95 \pm$ & 9.16 & 70.81 & $548.37 \pm$ \\
(S/S) & 1.29 & & 0.97 & 0.26 & 0.08 & \pm 0.49 & \pm 3.44 & 8.96
\end{tabular}

${ }^{*}$ Moisture in $\%$ wet weight. The results represent the mean \pm SD of three determinations.

Table III: Mineral element composition of the two soups (mg/100DM)

\begin{tabular}{l|c|c|c|c|c}
\multicolumn{1}{c|}{ Soup } & $\begin{array}{c}\text { Magnesium } \\
\mathbf{( M g})\end{array}$ & $\begin{array}{c}\text { Phosphorus } \\
\mathbf{( P )}\end{array}$ & $\begin{array}{c}\text { Potassium } \\
(\mathbf{K})\end{array}$ & $\begin{array}{c}\text { Calcium } \\
(\mathbf{C a})\end{array}$ & $\begin{array}{c}\text { Sodium } \\
\mathbf{( N a )}\end{array}$ \\
\hline Okro (S/W) & 275.61 & 556.08 & 797.81 & 1000.00 & 1329.28 \\
& \pm 0.95 & \pm 14.57 & \pm 5.63 & \pm 33.95 & \pm 120.44 \\
\hline Okro (S/S) & 205.76 & 556.81 & 673.34 & 1132.42 & 1803.95 \\
& \pm 12.97 & \pm 10.94 & \pm 8.61 & \pm 9.26 & \pm 130.47 \\
\hline Ogbono & 311.47 & 470.69 & 647.80 & 1956.70 & 1411.33 \\
(S/W) & \pm 12.25 & \pm 11.23 & \pm 3.26 & \pm 10.80 & \pm 34.22 \\
\hline Ogbono & 192.55 & 448.92 & 472.69 & 1109.59 & 3147.05 \\
(S/S) & \pm 17.94 & \pm 16.41 & \pm 25.13 & \pm 10.80 & \pm 298.81
\end{tabular}

Note: Results represent the Mean \pm SD of three determinations.

\section{DISCUSSION}

Most Nigerian soups are rich in protein, fat, ash and minerals depending on the economic power of the families and the improved recipe for the soups. The carbohydrate content of the meals consumed is usually derived from the main part of the meal either garri, foofoo or pounded yam and sometimes boiled rice. Soups consumed in the South-South regions have been shown to be high in the proximate composition and also in some of the mineral element composition. This may be attributed to the inclusion of the various sea foods in the soups and also the addition of fresh green leafy vegetables to almost every meal eaten in that region. In this study, ogbono and okro soups as prepared and consumed in the South-West and South-South regions of Nigeria were analysed to determine and compare the proximate and mineral element compositions.

The crude protein levels of the soups ranged form $19.89 \pm 0.13$ for ogbono soup (S/W) to $30.53 \pm$ 0.15 for okro soup (S/S). These results are lower than the results of Ekaidem (1995) who reported $38.81 \pm$
$0.15 \% \mathrm{DM}$ for okro soup (S/S) but showed that the soup can meet the recommended daily allowance for protein which FAO (1972) gave as between $21 \mathrm{~g}-65 \mathrm{~g}$ for an adult of $70 \mathrm{~kg}$ body weight. The crude protein levels of the South-South soups are significantly $(P<0.01)$ higher than in the South-West soups. This results also negates the assumption that the people in the South-West region of Nigeria consume high proportion of protein because of their love of meat. The crude fat levels ranged between $26.53 \pm 2.29$ in okro soup (South-West) to $40.17+0.07 \% D \bar{M}$ in ogbono soup (South-South). The high crude fat levels in ogbono soups could be attributed to the high crude fat content of Irvingia gabonensis seed about $68.42 \%$ (Agoha, 1993) and also the addition of palm oil to the soups during preparation. The carbohydrate content of the soups showed that okro soup (South-West) had the highest level at $34.55 \pm$ $0.06 \%$. These results showed that Nigerian soups should not be accessed in isolation but as a complete meal since the carbohydrate containing supplement will further increase the carbohydrate content of the meals. 
The minerals in the soups did not follow any particular pattern but the soups were rich in minerals and could meet their respective recommended daily allowances. The levels of $\mathrm{Ca}$ and $\mathrm{Na}$ were the highest in the soups with the calcium level in ogbono soup (South-West) significantly $(P<0.01)$ higher than the other soups. The Ca level in okro soup (South-South) was lower than the result of Akpanabiatu et al (1998). This variation could be due to the different methods of preparation, hence there is need to standardize soup preparation method. The recommended daily allowance for calcium in adults over the age of 24 is $800 \mathrm{mg}$, between 11 and 24 is $1200 \mathrm{mg}$ (Brody, 1994). The $\mathrm{Na}$ level in ogbono soup (South-South) is significantly higher than the peak of the recommended daily allowance of $2400 \mathrm{mg} / \mathrm{day}$ (N.R.C., 1994).

In conclusion, it is observed that the $S / S$ traditional recipe for the preparation of okro and ogbono soups is more nutritious in nutrient composition than the S/W recipe.

\section{REFERENCES}

A.O.A.C., 1993. Official Methods of Analysis. $15^{\text {th }}$ edition. Association of Official Analytical Chemists. Washington D.C.

Agoha, E. E. C., 1993. Chemistry and Technology of Breadmaking. Journal of Agriculture and Food Chemistry 25: $289-291$.

Akpanabiatu, M. I., Bassey, N. B., Udosen, E. O., and Eyong, E. U., 1998. Evaluation of some minerals and toxicants in some Nigerian soup meals. Journal of Composition and Analysis 11:292 - 297.

Aladasey, A. M., Oyakhilome, A., and Oshodi, A. A., 1983. Chemical and nutritional analysis of African bush mango seeds. International Tree Crop Journal 2(3): $46-48$.

Bender, A. E., 1966. Nutritional effects of food processing. Journal of Food Technology 1: 261 $-264$.

Brody, T., 1994. Nutritional Biochemistry. New York: Academic Press Incorporated.

Eka, O. U., 1984. A review of studies on changes in nutrient composition of foods. Nigerian Journal of Nutritional Science 5: $9-21$.

Ekaidem, I. S., 1995. Chemical and Biological evaluation of the nutritive value of melon soup, okro soup and plain (Afia Efere) soup. An unpublished B.Sc. Project. Department of Biochemistry, University of Calabar, Calabar, Nigeria.

Ekpe, O. O., 1997. Food potentials and nutritive values of ITUGHA (A processed product of Bush mango - Irvingia gabonensis) seed. A Ph.D Thesis. Department of Biochemistry, University of Calabar, Calabar, Nigeria.

Eyo, E. S.; Mohme, H. and Abel, H., 1981. A composition of carbohydrates and proteins in the seed of Irvingia gabonensis, Cucumeropsis manns et Macuna sleani. Plant Research and Development, 107 - 113.

FAO, 1972. Energy and protein requirements. Reports of a Joint Food and Agricultural Organization/World Health Organization and Ad hoc Expert Committee WHO technical representation, series 522 .

Latunde-Dada, G. O., 1990. Effects of processing on iron levels in and availability from some Nigerian vegetables. Journal of Science, Food Agriculture 53: 355 - 361 .

Lawal, O. O., 2007. Nutritional evaluation of Irvingia gabonensis and Hibiscus esculentus as prepared in the South-West and South-South regions of Nigeria. An unpublished M.Sc. (Nutrition and Food Science) Thesis. Department of Biochemistry, University of Calabar, Calabar, Nigeria. 107p.

Ngoddi, J. L.; Oben, J. E. and Minka, S. R., 2005. The effect of Irvingia gabonensis seeds on body weight and blood lipids of obese subjects in Cameroon. Lipid in Health and Disease, 4: 12 14.

NRC (1993/94) National Research Council. Recommended daily dietary allowance (United States of America). Nutritional Reviews 31: 374 $-395$.

Oyenuga, V. A., 1968. Nigerian Foods and Feeding Stuffs, their Chemistry and Nutritional Values. $3^{\text {rd }}$ edition. Ibadan University Press.

Platt, B. C., 1965. Tables of representative values of foods commonly used in tropical countries. Medical Reseach Council. Special Report Series 302. London: Her Majesty Stationery Office.

Spindler, S. and Akosionu, O., 1985. Gross composition of crude and diet fibres content of soup made with African bush mango seed. Nutritional Reports International 36: 1165 - 1169.

Udosen, E. O., 1995. Proximate and Mineral composition of some Nigerian vegetables. Discovery Innovations, 7(4), 383 - 386.

Umoh, I. B., 1972. Changes in the nutritive values of some Nigerian diets after cooking by Eastern Nigeria traditional methods. A Ph.D. Thesis. Department of Biochemistry, University of Ibadan, Ibadan, Nigeria. 